\title{
ERYTHROCYTE ALTERATIONS OF THE LAYING HENS SUBJECTED TO THERMAL STRESS
}

\author{
João Rogério Centenaro ${ }^{1 *}$, Larissa Grunitzky¹, Bárbara Abreu1, Natasha Rochada Silva1, Julia de \\ Moraes Pauloํㅜ, Alisson Minozzo. da Silveira ${ }^{1}$, Claucia Aparecida Honorato ${ }^{2}$, Rodrigo Garófallo \\ Garcia $^{2}$, and Paulo Henrique Braz ${ }^{1}$
}

\author{
1Instituto Federal Farroupilha - FredericoWestphalen, RS; ${ }^{2}$ Universidade Federal da Grande \\ Dourados - Dourados, MS
}

\section{ARTICLE INFO}

Article History:

Received $06^{\text {th }}$ March, 2021

Received in revised form

$21^{\text {st }}$ April, 2021

Accepted $08^{\text {th }}$ May, 2021

Published online $26^{\text {th }}$ June, 2021

\section{Key Words:}

Circadian rhythms, Heat, Hematimetry, Morphometry.

*Corresponding author: João Rogério Centenaro

ABSTRACT

The aim of this study was to identify erythrocyte changes resulting from heat stress in relation to different times of blood collection throughout the day. The experiment was carried out with 39 Rhode Island Red hens, in the initial laying phase, receiving standardized ad libitum feeding. The birds were placed in an environment of $20 \mathrm{~m}^{2}$, with controlled temperature, divided into 2 distinct groups: Control Group with 12 animals at $16^{\circ} \mathrm{C}$ and Experimental Group with 27 animals at $30^{\circ} \mathrm{C}$. Venipuncture took place at 7:00 am, 11:00 am and 3:00 pm. Blood was stored in an EDTA tube, aiming at cell preservation for further analysis. Total red blood cell count, hematimetry and erythroid morphometry were performed. After evaluating the erythroid and hematimetric parameters of the 39 birds, a negative correlation of heat stress was observed when comparing the different times of blood collection throughout the day. For morphometric correlation, there was a significant difference $(\mathrm{P}>0.01)$ at 3:00 pm. When evaluating the results between the times of blood collection from the same animal, it was observed that $55.5 \%$ reduced the hematocrit, while the total red blood cell count was reduced by $51.8 \%$. It is essential that there is a systematization of time in the collection of blood from laying hens.
\end{abstract}

Copyright (C) 2021, João Rogério Centenaro et al. This is an open access article distributed under the Creative Commons Attribution License, which permits unrestricted use, distribution, and reproduction in any medium, provided the original work is properly cited.

Citation: João Rogério Centenaro, Larissa Grunitzky, Bárbara Abreu, Natasha Rochada Silva, Julia de Moraes Paulo, Alisson Minozzo. da Silveira, Claucia Aparecida Honorato, Rodrigo Garófallo Garcia, and Paulo Henrique Braz, 2021. "Erythrocyte alterations of the laying hens subjected to thermal stress", International Journal of Development Research, 11, (06), 47911-47913.

\section{INTRODUCTION}

The hematological examination, considered as the main routine examination in veterinary medicine, has some peculiarities in relation to birds when compared to mammals. The smal amount of hematological studies in laying hens makes the blood count interpretation in these animals more difficult (Campbell, 2004; Lasser \& Weiser, 2006). In order to make a diagnosis of diseases in poultry, it is important knowing these animals physiological variations. These variations can be determined from serum changes in serial and comparative tests and that the exam be always from the same animal, in order not to compromise the expected results (Howlett et al., 1998; Campbell, 2004). Since the 1980s, cell morphometric parameters have been used to help determining the degree of hematological and neoplastic diseases in humans. However, no published data are obtained regarding laying hens and their physiological variations, highlighting the need for studies in this area (Brahmi et al., 2001). Due to the lack of information on reference levels for hematological indices in laying hens, the present study aimed to identify erythrocyte changes due to thermal stress compared to different blood collection times throughout the day.

\section{MATERIAL AND METHODS}

The project was authorized by the Comissão de Ética para Uso de Animais (CEUA/Oculto para revisão) under protocol number 5205220418. The experiment was carried out with 39 Rhode Island Red hens, in the initial laying phase, receiving a standardized ad libitum feeding containing $125 \mathrm{~g} / \mathrm{kg}$ of maximum moisture, $160 \mathrm{~g} / \mathrm{kg}$ of crude protein, $25 \mathrm{~g} / \mathrm{kg}$ of ether extract, $70 \mathrm{~g} / \mathrm{kg}$ of fibrous matter and $150 \mathrm{~g} / \mathrm{kg}$ of mineral matter. The birds were allocated in a $20 \mathrm{~m}^{2}$ environment, kept in a natural photoperiod, with temperature controlled by means of air conditioning, divided into two distinct groups:

G1: Control group containing 12 laying hens in an airconditioned environment at $16^{\circ} \mathrm{C}$ during seven days.

G2: Experimental group containing 27 laying hens in an airconditioned environment at $30^{\circ} \mathrm{C}$ during seven days.

Venipuncture was proceeded strictly at 7:00 am, 11:00 am and 3:00 $\mathrm{pm}$, for a complete blood count. The blood collection sites were the right jugular vein, the ulnar vein or the medial metatarsal vein, according to accessibility to the vein. 
Table 1. Correlation 2x3x2, observing two treatments, 3 blood collection times, 7:00 am, 11:00 am and 3:00 pm, and also the evaluation of two hematological parameters: erythroid and hematimetric count, in laying hens of the Rhode Island Red breed in early laying

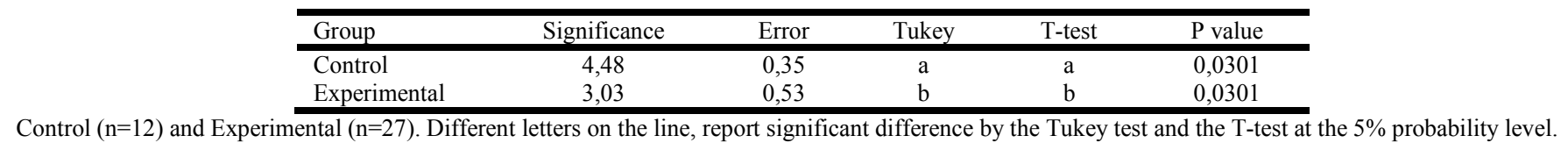

Table 2. Data obtained through erythrogram and erythroid morphometry

\begin{tabular}{lccccc}
\hline \multirow{2}{*}{ Grupo } & \multicolumn{3}{c}{ Hametimetry $(\%)$} & \multicolumn{2}{c}{${\text { Morfometria }\left(\mu m^{2}\right)}^{2}$} \\
\cline { 2 - 6 } & $7: 00 \mathrm{am}$ & $11: 00 \mathrm{am}$ & $3: 00 \mathrm{pm}$ & $7: 00 \mathrm{am}$ & $11: 00 \mathrm{am}$ \\
\hline Controle & $32,9 \pm 5,4$ & $25,3 \pm 2,3$ & $32,2 \pm 6,3$ & $27,7 \pm 4,2$ & $28,3 \pm 5,1$ \\
Experimental & $27,5 \pm 3,5$ & $25,6 \pm 2,9$ & $25,8 \pm 3,2$ & $27,0 \pm 4,2$ & $26,8 \pm 4,2$ \\
\hline Control (n=12) and Experimental (n=27).
\end{tabular}

Initially, asepsis was performed with $70 \%$ alcohol with the aid of gauze and punctured with a $13 \times 0.45 \mathrm{~mm}$ needle and $1 \mathrm{~mL}$ syringe. The amount of blood collected was according to the animal's weight, respecting the maximum limit of $0.5 \%$ of live weight. The blood was stored in a EDTA (ethylenediamine tetraacetic acid) containing tube for cell preservation and then a blood smear, total red blood cell count, hematimetry and erythroid morphometry were performed. The hematimetry technique was performed by filling a capillary tube with venous blood up to $3 / 4$ of its capacity, one extremity was closed in the flame of a lamp, and then it was centrifuged for five minutes at 3663 G. For the erythrocyte diameter measurement, five fields were randomly selected from each blood smear. After selecting the counting field, five erythrocytes with a larger apparent diameter and five erythrocytes with a smaller diameter were chosen, visually corresponding to the greatest variation of anisocytosis. Thus, for each blood smear, fifty red blood cells were measured. The slides were analyzed and photomicrographed with an Axioskop-Zeiss photomicroscope, with the aid of the software ZEN 2 (blue edition) ${ }^{\mathbb{B}}$ version 6.3.9600. To correlate the hematimetric values with the total amount of red blood cells at different times of blood collection, the Tukey and Test-t tests were used with a completely randomized design with a factor of $2 \times 3 \times 2$ with a $95 \%$ confidence index. The ANOVA test was used followed by the Tukey test with a $95 \%$ confidence index to evaluate the morphometric values between the same group of birds and compare different groups.

\section{RESULTS}

The hematimetric parameters of the birds exposed to a temperature of $16^{\circ} \mathrm{C}$ differed from those exposed to $30^{\circ} \mathrm{C}$. There was a negative correlation of thermal stress when compared to the different time of blood collection throughout the day (Table 1). For morphometric correlation between the different blood collection times that occurred throughout the day, when the control group compared to the experimental group, there was a significant difference $(\mathrm{P}>0.01)$ that occurred at 3:00 pm. The data obtained by the erythrogram and erythroid morphometry are presented in Table 2 . The average of the values found in the erythroid morphometry of the blood collected at 3:00 pm corroborates to the values of the globular volume. In both tests, it was possible to observe a decrease in cell diameter, since the erythrocyte area influenced the reduction in globular volume. Unlike the result above, the morphometric and globular volume data from 7:00 am and 11:00 am remained within the reference range, when compared to the experimental control group, differing only the group of birds with blood collection at 3:00 pm. Nutritional deficiency causes a decrease the muscle mass and a reduction in the weight of the birds. The control group obtained an average weight of $1.950 \mathrm{~g} \pm$ $255 \mathrm{~g}$, while the birds subjected to thermal stress obtained an average weight of $1.575 \mathrm{~g} \pm 202 \mathrm{~g}$. When evaluating the results between blood collection times of the same animal, it was observed that $55.5 \%$ $(15 / 27)$ of the animals had a reduced hematocrit degree, while the total red blood cell count had a reduction in their baseline values of $51.8 \%(14 / 27)$, both at light and critical levels.

\section{DISCUSSION}

The statistical difference reported in the hematimetric parameters of birds subjected to thermal stress can have several influential factors, such as the environment temperature, feather changes, reproductive state and photoperiod. Thus, it is necessary to know these physiological variations when assessing blood parameters (Campbell, 2004; Lasser \& Weiser, 2006). Due to the thermal stress to which the hens were exposed in the experimental group, it was expected that there would be a decrease in the amount of hydric and food intake, mainly, because of the thermal fatigue with respiratory decompensation. The values obtained from hematocrit indicate that the animals had relative anemia, associated with dehydration that occurred as a result of decreased water intake (Oliveira et al., 2014; Melo et al., 2016). The greater the animal's muscle mass, the greater the amount of red cells needed to maintain tissue perfusion, resulting in greater oxygenation. The decrease in hematocrit is also correlated with the weight loss of the animals evaluated, so it is worth noting that there is a greater energy expenditure for the heat stressed animals maintain homeostasis due to thermal stress (Ritchie et al., 1994; Vleck et al., 2000).

Several mechanisms have been described in order to explain the appearance of anemia during the egg production phase, correlating with the decrease in hematocrit levels and the number of red blood cells that can be an indirect effect of liver production, being it dependent on estrogen through the precursors the yolk and the mobilization of calcium ions, an osmotically active compound carried in high blood concentrations during the laying period. Anemic animals have decreased oxygen transport capacity and consequently compromise the animal's aerobic performance (Morton, 1994; Monaghan et al., 1998; Nager et al., 2001; Salvante \& Williams, 2002; Kalmbach et al., 2004). The morphometric classification of red blood cells depends on the values of mean corpuscular volume (MCV). However, a large cell volume must be altered to result in an abnormal value as observed in blood collected at $3 \mathrm{pm}$. We did not find in current literature reports where RDW (Red Cell Distribution Width) was evaluated in birds, however, the morphometry allows to visualize cell regeneration responses (Weiser, 1982; Ritchie et al., 1994).

The use of RDW together with the erythrocyte morphometry allows to distinguish whether the variation in the erythrocyte diameter is due to the encounter of macrocytes, microcytes or both, being more sensitive than when compared alone, therefore, new research in the area needs to be encouraged (Braz et al., 2017). The data found in this study, demonstrates that to laying hens there is the necessity of systematizaion about the blood collection time in any species of bird, be it from production, domestic to company or wild. Such findings about these hematological alterations cause changing of the condition and requirement of serum materials to be sent to veterinary clinical analysis laboratories (Ritchie et al., 1994; Melo et al., 2016). 


\section{CONCLUSIONS}

It is of great importance that, when collecting blood from laying hens, there is a time systematization in the execution of the procedure, since, when comparing results from different times on the same animal, there were differences in the results of red blood cell count and hematimetric and morphometric indices. In addition, thermal stress was another factor that generated changes in these evaluated parameters.

\section{Acknowledgment}

To the Fundação de Amparo à Pesquisa do Estado do Rio Grande do Sul (FAPERGS) by the Scientific Initiation scholarship supported by the Instituto Federal Farroupilha (Notice $n^{\circ}$ 049/2018).

\section{REFERENCES}

Brahmi U, Rajwanshi A, Joshi K, Dey P, Vohra H, Ganguly NK \& Gupta SK (2001). Automated nuclear image morphometry on fine needle aspiration smears of malignant round cell tumors. Anal. Quant. Cytol. Histol. 23 (4), 287-290.

Braz PH, Sartoretto MC, Souza AS, Siqueira MS (2017). Comparação entre os valores da amplitude de distribuição de diâmetro dos eritrócitos e do volume corpuscular médio com a citometria de eritrócitos em cães com leishmaniose. Pesq. Vet. Bras., 37 (7), 781-784.

Campbell TW (2004). Clinical chemistry of birds. In: Thrall MA. Veterinary Hematology and Clinical Chemistry. Lippincott, Williams and Wilkins, 479-492.

Howlett JC. (1998). Comparative Haematology International. Springer Verlag, 8, 26-30.
Kalmbach E (2004). Effects of experimentally increased egg production on female body condition and laying dates in the great skua Stercorarius skua. J. Avian Biol., 35, 501-514.

Lasser ED \& Weiser GL (2006). Laboratory technology for veterinary medicine. In: Thrall MA. Veterinary Hematology and Clinical Chemistry. Blackwell Publishing, 2, 3-88.

Melo AS (2016). Relação temperatura e nutrição sobre o desempenho de galinhas poedeiras. PUBVET, 10 (11), 855-860.

Monaghan P (1998). The price of eggs: Increased investment in egg production reduces the offspring rearing capacity of parents. Proc. Biol. Sci., 265, 1731-1735.

Morton ML (1994). Hematocrits in montane sparrows in relation to reproductive schedule. Condor, 96, 119-126.

Nager RG (2001). The cost of egg production: increased egg production educes future fitness in gulls. J. Avian Biol., 32, 159166.

Oliveira DL (2014). Desempenho e qualidade de ovos de galinhas poedeiras criadas em gaiolas enriquecidas e ambiente controlado. Rev. bras. eng. agríc. ambient., 18 (11), 1186-1191.

Ritchie BW (1994). Avian medicine: principles and application. Lake Worth, 1, 1384.

Salvante KG \& Williams TD (2002). Vitellogenin dynamics during egg-laying: daily variation, repeatability and relationship with egg size. J. Avian Biol., 33, 391-398.

Vleck CM (2000). Stress, corticosterone, and heterophil to lymphocyte ratios in free-living Adélie Penguins. Condor, 102 (2), 92-400.

Weiser MG (1982). Erythrocyte volume distribution analysis in healthy dogs, cats, horses, and dairy cows. Am. J. Vet. Res., 43, 163-166. 